\title{
Profil Pemecahan Masalah Siswa Pada Masalah Geometri ditinjau dari Perbedaan Jenis Kelamin dan Gaya Belajar
}

\author{
Gatot Soenarjadi ${ }^{1}$ \\ 1'SMA Negeri 11 Surabaya, tgt.gatot@gmail.com
}

\begin{abstract}
ABSTRAK
Tujuan penelitian ini adalah untuk menghasilkan profil pemecahan masalah siswa dengan jenis gaya belajar dan jenis kelamin yang berbeda dalam menyelesaikan masalah geometri. Sebanyak enam subjek diseleksi dengan mempertimbangkan variasi gaya belajar visual, auditori, dan kinestetik dan jenis kelamin. Data diperoleh melalui perekaman secara audiovisual dengan melakukan wawancara semi terstruktur berbasis tugas pemecahan masalah geometri kemudian. Data ini kemudian dianalisis dengan tahap reduksi, validasi, dan penyajian data menurut langkah-langkah pemecahan masalah Polya. Secara umum, tidak perbedaan yang signifikan pada profil pemecahan masalah geometri siswa laki-laki dan perempuan bergaya belajar visual, tetapi untuk keempat subjek lain menunjukkan bahwa subjek laki-laki lebih unggul daripada perempuan dalam tata ruang visual tetapi subjek perempuan lebih hati-hati dan akurat dalam proses pemecahan masalah yang dilakukan. Hasil penelitian ini berimplikasi pada rekomendasi pengajaran matematika yang dapat memfasilitasi pembelajaran geometri sesuai dengan karakteristik gaya belajar visual, auditori, dan kinestetik dalam kelas.
\end{abstract}

Kata Kunci: pemecahan masalah geometri, gaya belajar, auditori, kinestetik, visual, jenis kelamin

\begin{abstract}
This study aims to profile the problem solving processes of students with different types of learning styles and gender in solving geometry problems. A total of six participants were selected by considering variations in auditory, visual, and kinesthetic learning styles and gender. Data were obtained through audiovisual recording by conducting semi-structured interviews based on the task of solving geometry problems. The data was then analyzed with the stages of reduction, validation, and presentation of data according to Polya's problem solving steps. In general, the geometry problem solving profiles for male and female participants with visual learning styles do not show significant differences, but for the other four subjects it is shown that male participant was superior to women in visual layout but female subject was more careful and accurate in the problem solving processes. The results of this study have implications for mathematics teaching recommendations that can facilitate learning geometry in accordance with the characteristics of students regarding visual, auditory, and kinesthetic learning styles in the classroom.
\end{abstract} Key words: problem-solving in geometry, learning styles, auditory, visual, kinesthetic 


\section{Pendahuluan}

Geometri merupakan salah satu aspek yang penting untuk dipelajari siswa dalam rangka dapat mengembangkan logika berpikir dan intuisi keruangan yang berguna dalam pemecahan masalah yang banyak terkait dengan kehidupan sehari-hari. Sering kita temui siswa mengalami kesulitan belajar geometri, terutama dalam masalah yang berkaitan dengan kehidupan sehari-hari. Kesulitan siswa dalam menyelesaiakn masalah geometri dikarenakan pemahaman siswa yang lemah pada konsep geometri, dimana pengetahuan akan konsep-konspe ini menjadi pemahaman prasyarat bagi siswa untuk mempelajari materi geometri yang lebih kompleks [1]. Sebagaimana pendapat Hudojo [2] pengetahuan yang dipelajari seseorang bergantung kepada tingkat pengetahuan orang tersebut kuasai sebelumnya. Lebih khsusu, seseorang yang belajar matematika perlu memahami konsep 1 yang menjadi dasar konsep 2 dan setertusnya sehingga bersifat hirarki.

Kemampuan menyelesaikan masalah geometri telah dipelajari dipengaruhi oleh beberapa faktor seperti gaya kognitif [3], gaya belajar [4], tipe kecerdasan [5] dan jenis kelamin [6]. Lebih khusus, gaya belajar didefinisikan sebagai cara yang dilakukan oleh seseorang dalam memproses informasi yang masuk dengan lebih mudah dalam rangka menghasilkan perubahan yang lebih baik pada pemahaman yang ada pada orang tersebut. Setiap individu memiliki keistimewaan dalam melakukan proses informasi tersebut. Kajian teoretis telah menghasilkan paling tidak tiga macam gaya belajar menurut jenis pilihan sensori yang masuk, yaitu gaya belajar visual (penglihatan), auditori (pendengaran), kinestetik (sentuhan dan gerak). Siswa dengan gaya belajar visual akan sangat mudah melihat atau membayangkan apa yang dibicarakan. Selain itu, mereka senang memahmai suatu informasi suatu informasi dengan cara melihat suatu peristiwa, serta melihat satu informasi yang dikomunikasi dalam bentuk gambar [7] Sementara itu, siswa dengan gaya belajar auditori cenderung mengekspresikan diri mereka lewat suara baik dari eksternal maupun internal [7]. Siswa dengan gaya belajar kinestetik cenderung peka terhadap sensasi sentuhan dan gerakan, dimana jika ia diminta untuk menuliskan suatu kata atau kalimat maka ia akan mencoba merasakannya terlebih dahulu serta hasil belajarnya akan mencapai puncaknya jika dalam proses yang ia gunakan terkondisi dengan banyak melibatkan fisik dan gerakan [7].

Selain perbedaan gaya belajar, perbedaan gender juga memungkinkan adanya pengaruh terhadap profil siswa dalam memecahkan masalah geometri. Krutetskii [8] menjelaskan, anak perempuan memunyai kemampuan lebih dalam menyelesaiakn masalah geometri dalam hal ketelitian, kecermatan ketepatan, sedangkan anak laki-laki lebih baik dalam melibatkan penalaran ketika menyelesaikan masalah geomeri. DI sisi lain, Maccoby dan Jacklin [9] mempertgeas bahwa anak perempuan mempunyai kemampuan verbal lebih baik daripada anak laki-laki, sedangkan anak laki-laki lebih baik secara visual spasial daripada anak perempuan. Ia memberikan kesimpulan juga bahawa anak laki-laki lebih baik dalam kemampuan matematika.

Untuk mengidentifikasi proses pemecahan masalah geometeri berdasarkan gender atau gaya belajar, diperlukan sebuah kerangka analitik yang dapat mengakomodasi kebutuhan pengetahuan tentang proses kognitif yang terjadi pada seseorang ketika melakukan penyelesaian. Polya [10-11] mengajukan empat langkah proses kognitif dalam pemecahan masalah, yaitu memahami masalah, merencanakan pemecahan masalah, melaksanakan rencana penyelesaian masalah, dan memeriksa/melihat kembali hasil matematika yang diperoleh. Kemampuan memecahkan masalah tersebut sesungguhnya ada pada ide penyusunan rencana pemecahan masalah dimana kreatifitas daya temu dan pengertian mendalam sangat diperlukan. Dengan keunggulannya, kerangka analitik ini 
telah digunakan oleh banyak peneliti yang mengkaji proses kognitif individu dalam menyelesaikan masalah matematika [12-13].

Penelitian ini bertujuan untuk menghasilkan profil pemecahan masalah siswa pada tingkat sekolah menengah dengan jenis gaya belajar dan jenis kelamin yang berbeda dalam menyelesaikan masalah geometri. Gaya belajar yang dimaksud adalah gaya belajar visual, auditori, dan kinestetik.

\section{Metode Penelitian}

\subsection{Jenis Penelitian dan Subjek Penelitian}

Jenis penelitian ini adalah deskriptif eksploratif dengan pendekatan kualitatif dengan data utama berupa kata-kata yang tersusun secara deskriptif dalam bntuk kalimat-kalimat [14]. Analisis dilakukan secara mendalam tentang profil pemecahan masalah geometri yang diekspresikan oleh enam siswa di sebuah sekolah MTs di Surabaya dengan variasi gaya belajar dan jenis kelamin.

Peneliti menggunakan tes gaya belajar dari Chislett dan Chapman [15] untuk menentukan subjek penelitian. Tes ini diberikan kepada satu kelas di kelas VIII untuk kemdian diperoleh rincian masing-masing subjek dengan karakteristik gaya beajar dan jenis kelamin seperti yang disajikan dalam tabel 1 .

TABEL 1. Karakteristik subjek penelitian

\begin{tabular}{llll}
\hline \multirow{2}{*}{ Jenis Kelamin } & & \multicolumn{2}{c}{ Gaya Belajar } \\
& Visual (V) & Auditory (A) & Kinestetik (K) \\
\hline \multirow{2}{*}{ Laki-laki (L) } & Siswa Visual Laki-laki & Siswa Auditory Laki- & Siswa Kinestetik Laki-laki \\
& (VL) & laki (AL) & (KL) \\
& Siswa Visual & Siswa Auditory & Siswa Kinestetik \\
Perempuan (P) & Perempuan & Perempuan & Perempuan \\
& (VP) & (AP) & (KP) \\
\hline
\end{tabular}

Pertimbangan pemilihan subjek juga didasarkan pada ketersediaan subjek untuk dilibatkan dalam penelitian serta kemampaun komunikasikan secara lisan dan tulisan sesuai dengan informasi dari guru dan sekolah. Ketentuan pengambilan subjek berdasarkan gaya belajar didasarkan pada kriteria jika siswa memberikan respon lebih dari 15 pertanyaaan (dari 30 pertanyaan yang tersedia) pada respon yang menunjukkan salah satu dari gaya belajar (visual, kinestetik, atau auditori), maka ia terseleksi untuk dikategorikan pada siswa dengan gaya belajar tersebut.

\subsection{Teknik Pengumpulan dan Analisis Data}

Setelah subjek penelitian terpilih sebagaimana yang dimaksud dalam kriteria penentuan subjek penelitian, selanjutnya subjek diberi tes pemecahan masalah geometri. Dalam pelaksanaan tes pemecahan masalah geometri tersebut subjek mengerjakan soal yang dibuat oleh peneliti dan diwawancarai tentang hal-hal yang berkaitan dengan pelaksanaan tes tulis yang dilakukan oleh subjek. Setelah semua subjek melaksanakan tes yang pertama dan kedua, selanjutnya peneliti melakukan triangulasi data yang diperoleh dari hasil tes tersebut. Setelah diperoleh data yang konsisten dari triangulasi data, selanjutnya dianalisis. Data yang dianalisis dalam tes pemecahan masalah geometri tersebut bukanlah skor yang diperoleh siswa, melainkan profil subjek dalam memecahkan masalah geometri yang diberikan oleh peneliti 
Data berupa hasil wawancara berbasis tugas kemudian dianalisis dengan tahap-tahap seperti yang diungkapkan Miles dan Huberman [16]: 1) Menelaah seluruh data wawancara, dan hasil tes pemecahan masalah geometri oleh subjek. Kegiatan ini diawali dengan terlebih dahulu melakukan transkrip data wawancara yang berfokus pada kelompok jenis pertanyaan, jawaban, dan prilaku subjek berdasarkan hasil rekaman secara audio visual. Transkrip data yang dihasilkan kemudian diseleksi, diabstraksi, dan diformulasikan dengan cara mengambil intisari dari transkrip yang diperoleh dari hasil wawancara, 2. Mereduksi data dengan tujuan menajamkan, mengarahkan, menggolongkan, membuang yang data yang tidak relevan, 3. Memvalidasi data dengan cara mengecek berulang pada waktu yang berbeda, dimana tahap ini bertujuan untuk mengecek tingkat kepercayaan suatu informasi dalam rangka triangulasi data. Triangulasi yang digunakan dalam penelitian ini adalah triangulasi waktu, yang mana jeda anatara pengumpulan data pertama dan kedua adalah tujuh hari. 4. Memaparkan/ Menyajikan data yang meliputi kegiatan mengklasifikasi dan mengidentifikasi data dengan tujuan mempermudah peneliti memahami data hasil interpretasi serta merencanakan tahap selanjutnya dalam rangka penarikan kesimpulan dari semua data yang ditelaah. 5. Menarik kesimpulan denagn merujuk pada hasil analisis dari data hasil pekerjaan subjek maupun wawancara. Hasil dari penarikan kesimpulan ini kemudian dijadikan sevagai dasar utama dalam mengkonstruksi rumusan profil pemecahan masalah siswa dalam menyelesaikan masalah geometri berdasarkan langkah-langkah pemecahan Polya.

\section{Hasil Penelitian}

\subsection{Profil subjek dengan gaya belajar visual dalam memecahkan masalah geometri}

Profil pemecahan masalah geometri subjek VL adalah sebagai berikut. VL mulai dengan memahami masalah dengan cara membaca lembar soal pemecahan masalah secara berulang-ulang serta memandang ke arah tertentu seperti memikirkan sesuatu, dan sesekali membuat coret-coretan di lembar soal. Subjek memahami masalah ditunjukkan dengan subjek dapat menyebutkan apa yang ditanyakan yaitu jalur mana yang lebih cepat sampai ke tujuan dan apa yang diketahui dari soal yang sudah subjek pelajari yaitu bentuk jalur jalan yang dipandang sebagai bangun datar segitiga siku-siku yang merupakan salahsatu bentuk bangun datar dalam geometri. Hal ini seperti yang diungkapkan VL berikut.

VL1-2 : (sambil sesekali membaca lembar soal subjek menjawab) terdapat dua jalur jalan untuk menuju ke sekolah yang membentuk segitiga siku-siku. (terdiam sejenak sambil tetap membaca lembar soal) Jalan yang membentuk siku-siku masing-masing berjarak $9 \mathrm{~km}$ dan $12 \mathrm{~km}$, jalan yang membentuk siku-siku ini kondisinya lebih baik daripada jalan yang langsung (terdiam sejenak sambil membaca lembar soal kembali, kemudian melanjutkan) jalan yang kondisinya lebih baik kecepatannya $15 \mathrm{~km} / \mathrm{jam}$ dan jalan yang kurang baik kecepatannya $12 \mathrm{~km} / \mathrm{jam}$. Yang ditanyakan adalah jalur jalan mana yang dipilih agar lebih cepat sampai ke sekolah

Selanjutnya VL merencanakan pemecahan masalah dengan menggunakan pengetahuan sebelumnya yaitu teorema Phytagoras untuk menghitung jarak jalan yang lurus karena memandang bentuk jalur jalan sebagai bangun datar segitiga siku-siku dan rumus kecepatan untuk menghitung waktu tempuh pada masing-masing jalur. Dalam 
merencanakan pemecahkan masalah terlihat membaca lembar soal beberapa kali dan terdiam sejenak memandang ke suatu arah seperti memikirkan sesuatu.

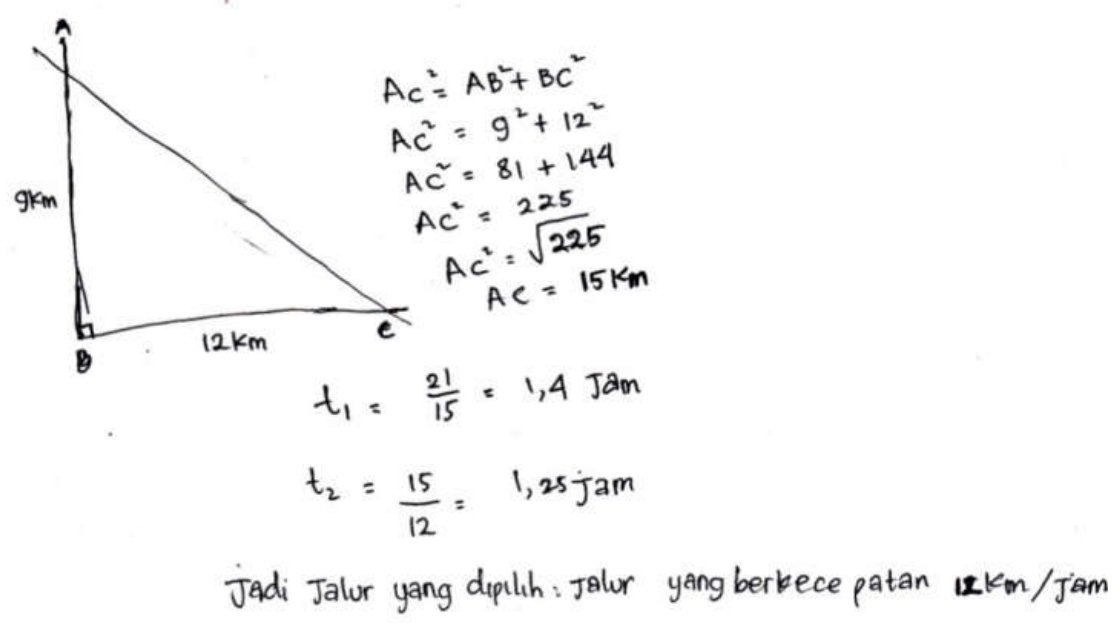

Gambar 1. Hasil Pekerjaan subjek VL

Gambar 1 secara lebih rinci memperlihatkan bagaimana VL melaksanakan rencana penyelesaiannya. Dalam melaksanakan rencana pemecahan masalah, VL melakukan sesuai dengan rencana dan runtut yaitu menggunakan teorema Pythagoras untuk menghitung jarak jalan yang lurus dan menentukan waktu yang diperlukan untuk menempuh masing-masing jalur menggunakan rumus kecepatan, kemudian menyimpulkan hasil pekerjaan untuk menjawab pertanyaan dengan menyatakan kecepatannya. Langkah terakhir, yaitu memeriksa kembali hasil pekerjaann, dilakukan VL untuk memastikan langkah yang ia lakukan sudah sesuai rencana atau belum. Selain itu, ia sesekali melihat kembali hasil pekerjaannya dan lembar soal sambil memandang ke arah tertentu secaar konsisten seperti tampak memikirkan sesuatu.

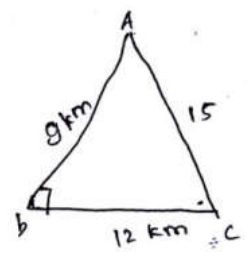

$$
\begin{aligned}
A C^{2} & =b c^{n}+A b^{2} \\
A C & =12^{2}+9 \mathrm{~km} \\
A C & =144+81 \\
& =225 \\
& =225 \\
& =15
\end{aligned}
$$

$t_{1}=\frac{15}{12}=+1151,25$

$t_{2}=\frac{21}{15}=1,4$

lebih cepat tewat jalur lurus

Gambar 2. Hasil pekerjaan subjek VP

Selanjutnya, profil pemecahan masalah geometri subjek visual berjenis kelamin perempuan (VP) adalah sebagai berikut. VP mengawali proses dengan memahami 
masalah. Tahap ini ia lakukan dengan cara membaca beberapa kali lembar soal dan sesekali memandang ke suatu arah seperti memikirkan sesuatu sambil mencoret-coret di atas yang ditunjukkan dengan menyebutkan apa yang ditanyakan yaitu jalur jalan mana yang harus dilalui agar lebih cepat sampai ke tujuan dan apa yang diketahui dari soal yaitu bentuk jalur jalan yang dipandang sebagai bangun datar segitiga siku-siku yang merupakan salahsatu bentuk bangun datar dalam geometri. Pada tahap selanjutnya, yaitu merencanakan pemecahan masalah, ia menggunakan pengetahuan sebelumnya yaitu teorema Phytagoras karena memandang bentuk jalur jalan yang dimaksud sebagai bangun datar segitiga siku-siku dan rumus kecepatan untuk menentukan waktu yang diperlukan jika melalui masing-masing jalur, yang waktunya lebih kecil berarti lebih cepat sampai tujuan. Dalam merencanakan pemecahkan masalah terlihat membaca lembar soal beberapa kali sambil sesekali memandang ke suatu arah seperti memikirkan sesuatu.

Tahap selanjutnya, yaitu melaksanakan rencana pemecahan masalah geometri, dilakukan VP sesuai dengan runtut sesuai rencana yaitu menggunakan teorema Pythagoras untuk menentukan panjang jalur yang lurus dan menghitung waktu yang diperlukan jika melalui masing-masing jalur menggunakan rumus kecepatan. Untuk memperjelas, ia menggambar bangun datar segitiga siku-siku untuk memudahkan melaksanakan rencana menyelesaikan soal. Selama menyelesaikan soal, terlihat beberapa kali membaca lembar soal dan melihat hasil pekerjaannya sambil memandang ke suatu arah seperti memikirkan sesuatu. Tahap memeriksa kembali hasil pekerjaan dilakukan VP untuk memastikan apakah langkah yang dilakukan sudah sesuai dengan rencana dan sudah menjawab pertanyaan dengan cara melihat kembali hasil pekerjaannya dan membaca kembali lembar soal beberapa kali sambil sesekali memandang ke suatu arah seperti memikirkan sesuatu. Dapat menjelaskan bahwa hasil pekerjaannya sudah menjawab pertanyaan yang dimaksud dalam soal.

\subsection{Profil subjek dengan gaya belajar auditory dalam memecahkan masalah geometri}

Profil Auditory berjenis kelamin Laki-laki (AL) dalam menyelesaikan masalah geometri adalah sebagai berikut. AL memahami masalah dengan cara membaca lembar soal beberapa kali dengan sedikit bersuara dan dapat menyebutkan apa yang ditanyakan yaitu melalui jalur jalan mana agar lebih cepat sampai ke tujuan dan apa yang diketahui yaitu bentuk jalur jalan yang dipandang sebagai bangun datar segitiga siku-siku yang merupakan salah satu bentuk bangun datar dalam geometri. Lalu, ia merencanakan pemecahan masalah dengan cara membaca lembar soal beberapa kali. Uniknya, ia melakukannya dengan sedikit bersuara sambil sesekali memandang ke sarah tertentu seperti tampak sedang memikirkan sesuatu. Hasil dari rencana ini ia uangkapkan dengan keinginan untuk menerapkan teorema Pythagoras seperti yang telah ia pelajari sebelumnya. Hal ini dilakukan dengan alasan subjek memandang bentuk jalur jalannya sebagai bangun datar segitiga siku-siku dan rumus kecepatan untuk menentukan waktu tempuh masing-masing jalur jalan. Kemudian, ia menyimpulkan bahwa yang waktunya lebih sedikit berarti lebih cepat sampai ke tujuan. Hal ini ditunjukkan oleh petikan wawancara berikut.

P: Mengapa kamu memilih jalan yang siku-siku?

AL: (Terdiam sambil melihat hasil pekerjaannya kemudian memandang ke

arah tertentu sambil menggerakkan bibir seperti tampak berbicara sendiri

dan sejenak kemudian menjawab) Karena waktunya lebih sedikit.

P: Bagaimana kamu bisa menjawab demikian? 
AL: (Terdiam sejenak sambil melihat lagi hasil pekerjaannya kemudian memandang ke suatu arah sambil menggerakkan bibirnya seperti berbicara sendiri, sejenak kemudian menjawab) karena waktunya lebih sedikit jadi lebih cepat (terdiam dan sejenak kemudian) jadi jalan yang dipilih adalah yang siku-siku.

Tahap melaksanakan rencana pemecahan masalah dilakukan sesuai dengan rencana dan runtut menggunakan teorema Phytagoras untuk menentukan panjang jalur jalan yang lurus dan menentukan waktu tempuh masing-masing jalur dengan menerapkan rumus kecepatan,. Untuk itu, ia melihat kembali hasil pekerjan dan lembar soal di depannya secara bergantian sambil memandang ke suatu arah sambil menggerakkan bibirnya seperti tampak berbicara sendiri dan memainkan bolpoinnya. Menggambar situasi jalan yang dimaksud dalam soal dengan menggambar bangun datar segitiga siku-siku bertujuan untuk memudahkan melaksanakan rencana pemecahan masalah. Ia kemudian memeriksa kembali hasil pekerjaannya untuk memastikan apakah langkahnya sudah sesuai dengan rencana dan sudah menjawab pertanyaan dengan cara melihat kembali lembar soal dan hasil pekerjaannya secara bergantian dan sesekali memandang ke suatu arah seperti memikirkan sesuatu sambil menggerakkan bibirnya seperti berbicara sendiri dan memainkan bolpoinnya serta dapat menjelaskan bahwa hasil pekerjaannya sudah menjawab pertanyaan yang dimaksud dalam soal.
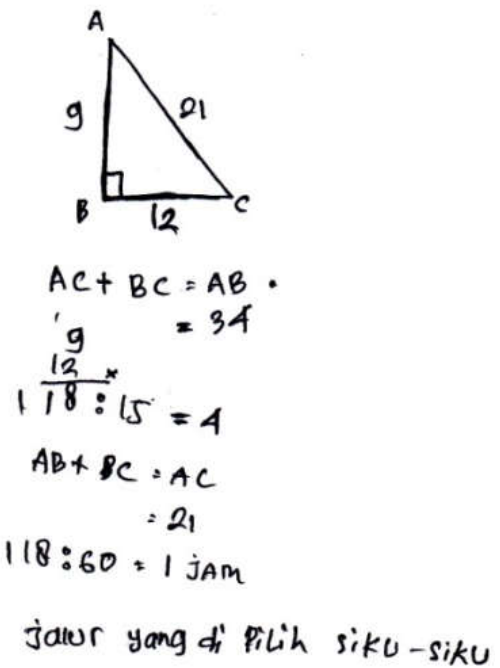

Gambar 3. Hasil pekerjaan AL

Sementara itu, subjek Auditory berjenis kelamin Perempuan (AP) melakukan pemecahan masalah dengan tahap-tahap berikut. Ia mulai dengan memahami masalah dengan cara membaca lembar soal beberapa kali dengan sesekali terdiam beberapa saat berkonsentrasi sambil mencoba memahami lembar soal dengan sedikit bersuara. Proses ini ditunjukkan dengan dapat menyebutkan apa yang ditanyakan yaitu melalui jalur jalan yang mana agar lebih cepat sampai ke tujuan dan apa yang diketahui dari soal yaitu bentuk jalur jalan yang dipandang sebagai bangun datar segitiga siku-siku yang merupakan salahsatu bentuk bangun datar dalam geometri. Dalam merencanakan pemecahan masalah, ia mengaku menggunakan pengetahuan sebelumnya yaitu teorema Pythagoras untuk menghitung jarak jalan yang lurus karena subjek memandang bentuk jalurnya sebagai bangun datar segitiga siku-siku dan menghitung waktu tempuh masing-masing jalur menggunakan rumus kecepatan, yang waktunya lebih sedikit berarti lebih cepat sampai ke tujuan. 
AP: Karena jalur jalannya membentuk segitiga siku-siku maka menghitung jarak jalan yang lurus menggunakan rumus phytagoras, kemudian menghitung waktu yang diperlukan untuk menempuh jarak masingmasing jalur jalan menggunakan rumus kecepatan, (beberapa saat terdiam, berkonsentrasi sambil memandang lembar soal kemudian melanjutkan) yang waktunya lebih sedikit berarti lebih cepat sampai ke sekolah.

P: Jadi kamu nanti akan mencari waktu yang diperlukan untuk menempuh jalur jalan yang lurus dan jalur jalan yang membentuk siku-siku, begitu?

AP: Ya (Jawabnya singkat)

Pada tahap selanjutnya, AP melaksanakan pemecahan masalah sesuai dengan rencana dan runtut yaitu menggunakan teorema Pythagoras untuk menghitung jarak jalan yang lurus dan menghitung waktu tempuh masing-masing jalur menggunakan rumus kecepatan, yang waktunya lebih sedikit berarti lebih cepat, kemudian menyimpulkan hasil pekerjaan untuk menjawab pertanyaan dengan menyatakan bentuk jalurnya. Ia menggambar bangun datar segitiga siku-siku untuk memudahkan melaksanakan rencana menyelesaikan soal (lihat gambar 4). Hasil pengamatan menunjukkan ia beberapa kali terdiam beberapa saat berkonsentrasi sambil membaca lembar soal dan melihat hasil pekerjaannya bergantian. Dengan memperhatikan gesture, tampak bahwa subjek sesekali melakukan gerakan jari sambil menggerakkan bibir dan bersuara seperti berbicara sendiri secara lirih. Pada tahap memeriksa kembali, AP tampak memandang kembali lembar soal dan hasil pekerjaannya secara bergantian sampai beberapa kali dengan sesekali terdiam seperti tampak berkonsentrasi. Dalam melakukan ini, ia juga menggerakkan jari-jarinya serta bersuara lirih seperti mengucapkan sesuatu.

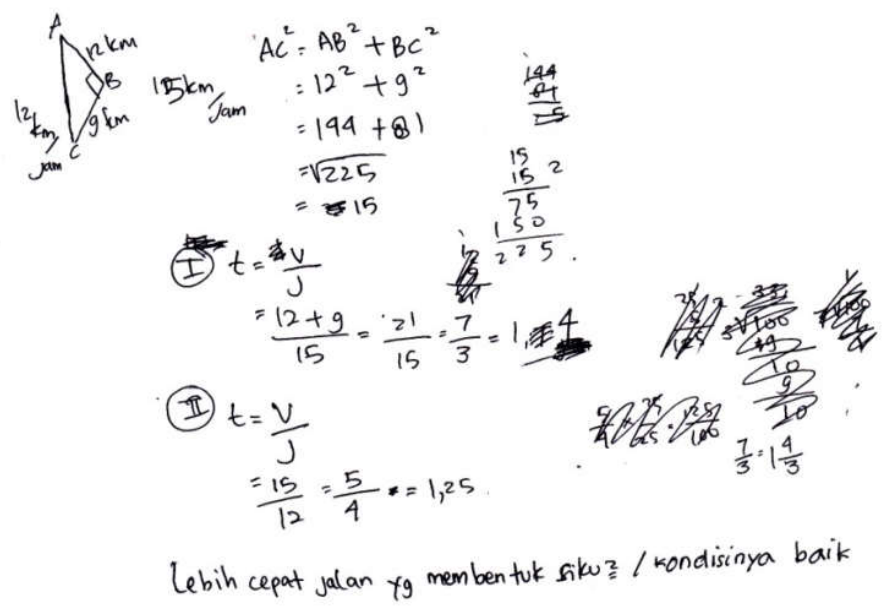

Gambar 4. Hasil Tes Tulis Subjek AP

\subsection{Profil subjek dengan gaya belajar kinestetik dalam memecahkan masalah geometri}

Profil pemecahan masalah KL adalah sebagai berikut. KL mulai memahami masalah dengan cara membaca lembar soal sambil sambil sesekali menggerakkan jari-jari 
tangannya memainkan alat tulis penanya Hasil pengamatan menunjukkan bahwa KL melakukan tahap ini dengan tepat yang ditunjukkan oleh kemampuannya menyebutkan apa yang diketahui dari soal yaitu bentuk jalur jalan yang dipandang sebagai bangun datar segitiga siku-siku yang merupakan salah satu bangun datar dalam geometri dan apa yang ditanyakan, yaitu jalur jalan yang mana yang harus dilalui agar lebih cepat sampai ke tujuan. Kemudian ia merencanakan pemecahan masalah dengan menggunakan pengetahuan sebelumnya yaitu untuk menghitung jarak jalur yang lurus menggunakan teorema Phytagoras karena memandang bentuk jalur jalannya sebagai bangun datar segitiga siku-siku dan untuk menghitung waktu yang diperlukan menempuh jalur masingmasing menggunakan rumus kecepatan, yang waktunya lebih pendek berarti lebih cepat sampai ke tujuan. Dalam merencanakan pemecahkan masalah, KL tampak mengangkat lembar soal untuk membaca soal, dan sesekali memainkan pena dan menggerakkan jemarinya. Hal ini seperti yang ditunjukkan petikan wawancara berikut.

P: $\quad$ Coba sekarang jelaskan langkah yang kamu lakukan tadi.

KL: (Subjek terdiam sambil melihat-lihat hasil pekerjaannya dan sesaat kemudian) Jarak jalan yang lurus diperoleh dari 9 kuadrat ditambah 12 kuadrat terus diakar hasilnya 15. (Terdiam sejenak sambil memainkan bolpoin, kemudian melanjutkan) Kemudian menghitung waktu yang diperlukan kalau lewat jalan yang siku-siku adalah 9+12 sama dengan 21 kemudian dibagi 15 sama dengan 1,4 jam, dan kalau lewat jalan yang langsung waktu yang diperlukan adalah 15 dibagi 12 samadengan 1,25 jam. (Terdiam sejenak sambil melihat-lihat hasil pekerjaannya dan menggerakkan jemarinya kemudian melanjutkan) Jadi jalur yang dipilih adalah jalur yang lurus.

Selanjutnya, KL melaksanakan pemecahan masalah sesuai dengan rencana dan runtut yaitu menggunakan teorema Pythagoras untuk menghitung jarak jalan yang lurus dan menghitung waktu yang diperlukan jika melalui masing-masing jalur menggunakan rumus kecepatan dan waktu yang lebih sedikit menunjukkan lebih cepat, kemudian menyimpulkan hasil pekerjaan untuk menjawab pertanyaan dengan menyatakan bentuk jalur dan kecepatannya. Lihat gambar 5.

1)
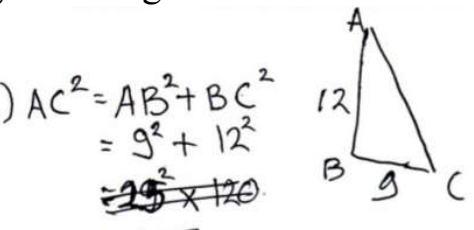

$=2$

$=81+144=225=15$

$\frac{15}{12}=\frac{5}{4}=1,25$

$\frac{21}{15}=1,4$

lebih cepat yanglurus kecepatan $12 \mathrm{~km} / \mathrm{gam}$
waktunya lebih pendek

Gambar 5. Hasil pekerjaaan subjek KL 
Sama halnya dengan tahap sebelumnya, KL terlihat beberapa kali menggerakkan jemarinya, kemudian membaca lembar soal dan melihat hasil pekerjaannya sambil memainkan bolpoin, dan sesekali menggoyangkan kakinya pada saat melaksanakan rencana penyelesaiannya. Untuk memeriksa kembali hasil pekerjaan, KL melihat kembali hasil pekerjaannya dan lembar soal beberapa kali sambil sesekali memainkan bolpoin dan jemarinya. Menggambar bangun datar segitiga siku-siku untuk memudahkan memeriksa kembali hasil pekerjaannya serta dapat menjelaskan bahwa hasil pekerjaannya sudah menjawab pertanyaan yang dimaksud dalam soal.

Sementara itu, profil pemecahan masalah subjek KP adalah sebagai berikut. Secara umum, yang dilakukan KP sama dengan KL dalam hal menggerakan jari-jari tangannya serta menganggkat lembar soalnya. Pada tahap ini, KP dapat menyebutkan apa yang ditanyakan yaitu jalur jalan yang mana yang harus dilalui agar lebih cepat sampai ke tujuan dan apa yang diketahui dari soal yaitu bentuk jalur jalan yang dipandang sebagai bangun datar segitiga siku-siku yang merupakan salahsatu bentuk bangun datar dalam geometri. Selanjutnya, KP menyusun rencana pemecahan masalah denga cara menggunakan pengetahuan sebelumnya yaitu aplikasi teorema Phytagoras untuk menghitung jarak jalan yang lurus menggunakan karena memandang bentuk jalur jalannya sebagai bangun datar segitiga siku-siku dan menghitung waktu yang diperlukan untuk menempuh masing-masing jalur menggunakan rumus kecepatan, yang waktunya lebih kecil artinya lebih cepat sampai ke tujuan. Klaim ini ditunjukkan oleh hasil wawancara berikut.

KP: (Subjek terdiam sambil memainkan bolpoin dan melihat-lihat hasil pekerjaannya, sesaat kemudian) Jalan yang lurus diperoleh dari 9 kuadrat ditambah 12 kuadrat terus diakar hasilnya 15. (Terdiam sejenak sambil memainkan bolpoin dan menggerakkan jemarinya, kemudian melanjutkan) Kemudian menghitung waktu yang diperlukan kalau lewat jalan yang siku-siku adalah 9+12 sama dengan 21 kemudian dibagi 15 sama dengan 1,4 jam, dan kalau lewat jalan yang langsung waktu yang diperlukan adalah 15 dibagi 12 samadengan 1,25 jam. (Terdiam sejenak sambil menggerakkan jemarinya dan melihat-lihat hasil pekerjaannya kemudian melanjutkan) Jadi jalur yang dipilih adalah jalur yang lurus.

P: $\quad$ Mengapa kamu memilih jalur yang lurus?

KP: (Terdiam sambil melihat hasil pekerjaannya dan sejenak kemudian menjawab) Karena kalau melewati jalur yang lurus waktu yang diperlukan lebih sedikit.

P: Bukankah jalur yang lurus itu kondisi jalannya kurang baik?

KP: Iya, (Terdiam sejenak sambil melihat lagi hasil pekerjaannya, kemudian menjawab) tapi waktu yang diperlukan lebih pendek (terdiam sambil memainkan bolpoin dan sejenak kemudian) jadi memilih jalur yang lurus agar lebih cepat sampai ke sekolah.

Dalam melaksanakan pemecahan masalah, KP melakukan proses ini sesuai dengan rencana dan runtut yaitu menggunakan teorema Pythagoras untuk menghitung jarak jalan yang lurus dan menggunakan rumus kecepatan untuk menghitung waktu yang diperlukan menempuh masing-masing jalur, yang waktunya lebih sedikit berarti lebih cepat, kemudian menyimpulkan hasil pekerjaan untuk menjawab pertanyaan dengan lengkap beserta alasannya. Untuk itu, ia menggambar bangun datar segitiga siku-siku untuk memudahkan melaksanakan rencana menyelesaikan soal. Lihat gambar 6. 


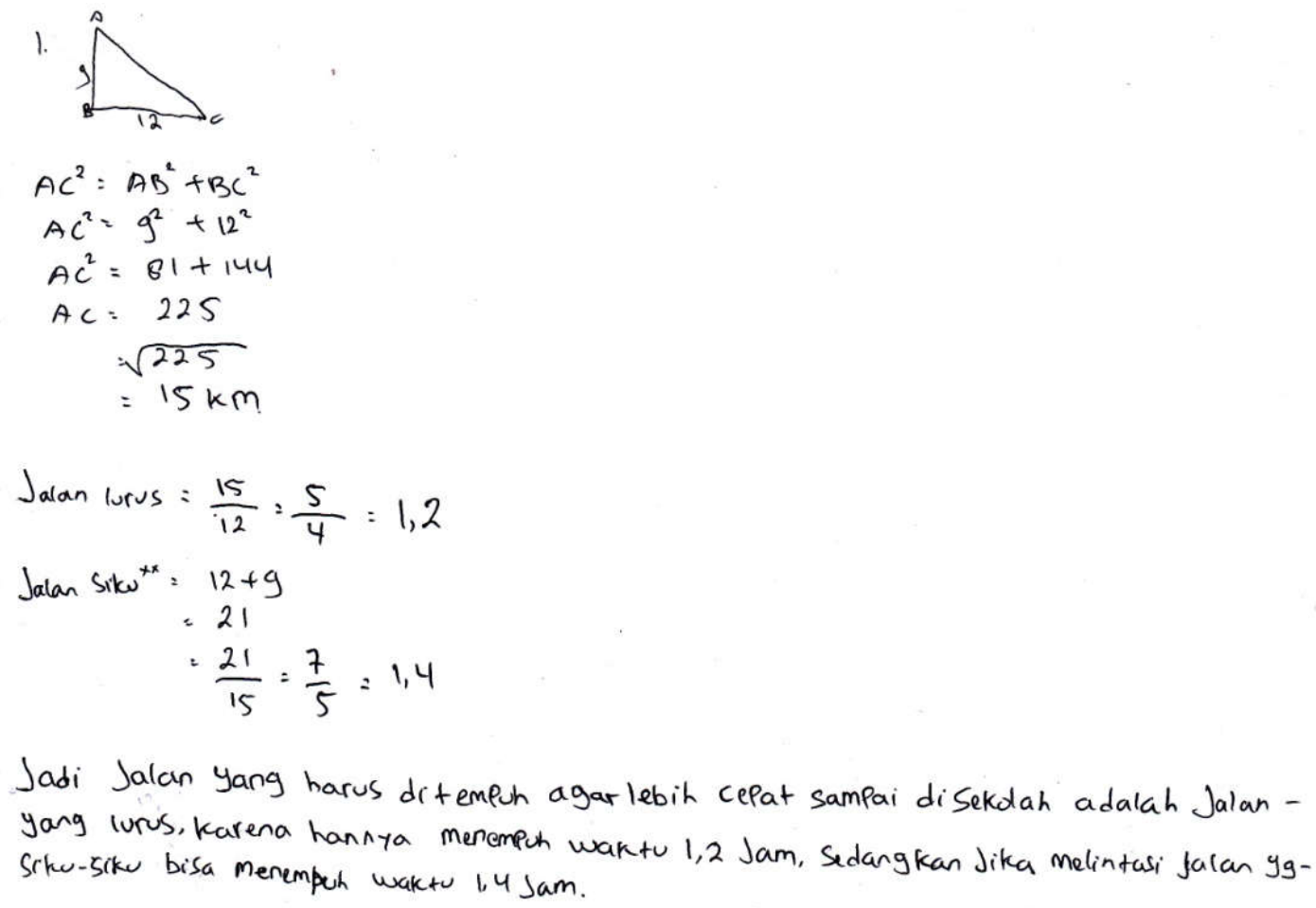

Gambar 6. Hasil pekerjaan subjek KP

Sama halnya dengan tahap sebelumnya, KP melaksanakan rencana penyelesaian dengan cara menunjukkan jari ke lembar soal sambil mengangkatnya. Pada tahap memeriksa kembali, KP melihat kembali hasil pekerjaannya untuk meyakinkan apakah langkahnya sudah sesuai dengan rencana dan sudah menjawab pertanyaan dengan cara melihat kembali hasil pekerjaannya dan lembar soal beberapa kali sambil menunjukkan jarinya dan sesekali memainkan bolpoin serta dapat menjelaskan bahwa hasil pekerjaannya sudah menjawab pertanyaan yang dimaksud dalam soal.

\subsection{Diskusi Hasil Penelitian}

Hasil penelitian menunjukkan bahwa semua subjek menggunakan gambar sebagai sarana subjek melakukan pemecahan masalah geometri. Hal ini menunjukkan bahwa menggunakan gambar tidak hanya menjadi pilihan subjek visual saja tetapi juga menjadi pilihan bagi subjek auditori dan kinestetik memudahkan subjek melakukan menyelesaikan masalah geometri. Ini menunjukkan bahwa representasi geometris memegang peran penting bagi setiap pemecah soal (problem-solver) dalam proses pemecahan masalahnya. Temuan ini didukung oleh Copeland [17] yang mengungkapkan bahwa memang pengalaman pengalaman matematika pertama anak ketika mereka menggali informasi objek-objek dalam ruang lebih bersifat geometri daripada aritmatika.

Secara sequensial, proses pemecahan masalah yang dilakukan oleh subjek dapat digambarkan sebagai berikut. Pada tahap memahami masalah, semua subjek memandang masalah geometri dalam persepktif geometeri, dimana segitiga sikusiku dan teorema Pythagoras sebagai ide kunci dalam memahami masalah. Hal ini mengindikasikan bahwa semua subjek melakukan abstraksi masalah ke dalam pendekatan geometris meskipun pada soal tidak disajikan bangun geometri tertentu secara eksplisit. Pemanfaatan gambar juga dilakukan oleh semua subjek pada tahap merencanakan penyelesaian masalah dan pemeriksaan hasil pekerjaan. Temuan ini menunjukkan bahwa proses peyelesaian 
masalah geometeri ini sesuai dengan tujuan pembelajaran geometri yaitu untuk mengembangkan kemampuan berpikir logis, mengembangkan intuisi keruangan, menanamkan pengetahuan untuk menunjang materi yang lain, dan dapat membaca serta menginterpretasikan angan-angan matematika [18].

Pemahaman terhadap hasil penelitian ini didukung oleh temuan-temuan terkait kemampuan seseorang dalam menyelesaiakn masalah matematika ditinjau dari gender dan gaya belajar. Sebagai contoh, temuan bahwa profil pemecahan masalah geometri antara VL dan VP tidak menunjukkan perbedaan yang signifikan mendukung hasil penelitian Rahman dan Asmar [6] yang menemukan bahwa tidak ada hubungan antara variabel gaya belajar, jenis kelamin dan interaksi gaya belajar dengan jenis kelamin terhadap prestasi belajar. Hal ini memberikan rekomendasi bahwa ada faktor lain yang dianggap lebih penting dalam mempengaruhi seseorang untuk berhasil memecahkan sebuah masalah matematika. Menurut Zeybak [19], faktor yang lebih berpengaruh dalam kesuksesan belajar geometri adalah faktor daya juang (struggling) dimana setiap pengajaran geometri, khusunya, seorang guru perlu memberikan kesempatan siswa untuk berjuang dengan ide-ide matematika agar dapat mendukung pengembangan pemahaman konseptual siswa tentang matematika.

Bagaimanapun, penelitian ini memiliki beberapa keterbatasan. Teori yang digunakan dalam rangka mengungkap aktifitas subjek yang dikemukakan pada tesis ini sebatas pada penerapan kerangka analitik tahapan Polya sebagai landasan analisis profil siswa. Padahal, dalam mengkaji profil siswa, gesture tubuh menjadi poin ideal untuk didiskusika. Sementara kerangka ini tidak melingkupi bagaimana menganalisis hestur tubuh dalam rangka memperkuat temuan profil pemecahan masalah siswa. Untuk itu, dalam penelitian selanjutnya, peneliti merekomendasikan untuk mengkaji lebih dalam terkiat teori yang melandasi siswa dalam melakukan proses berpikir ditinjau dari gesture tubuh yang digunakan, seperti dengan kajian teori enaktivisme dalam pendidikan matematika [20]. Keterbatasan ini menyebabkan analisis yang diberikan terhadap proses pemecahan masalah siswa dalam menyelesaikan masalah geometri hanya terbatas pada data empiric hasil telaah pekerjaan siswa dan data wawancara yang didukung oleh teori yang ada.

\section{Penutup}

Secara umum, profil pemecahan masalah subjek laki laki dan perempuan mengiktui pola yang diungkap penelitian dari kajian teoretis sebelumnya. Bahwa profil pemecahan masalah geometri antara subjek visual laki-laki (VL) dan subjek baik subjek kinestettik, auditori, maupun visual laki-laki masing-masing lebih unggul dalam melakukan visualiasi pada setiap langkah pemecahan masalah. Dalam hal ketelitian, kecermatan, dan keseksamaan dalam menyajikan langkah-langkah penyelesaian, subjek perempuan pada semua jenis gaya belajar lebih unggul daripada laki-laki.

Hasil penelitian ini memberikan rekomendasi setiap guru matematika perlu menyadari adanya kecenderungan cara belajar yang berbeda-beda pada siswa-siswa di kelas. Dengan demikian, secara praktis, penelitian ini menyarankan guru untuk menyelenggarakan pembelajaran yang dapat memfasilitasi siswa dalam belajar sesuai dengan karakteristik gaya belajar masing-masing. Lebiih khusus, dalam pembelajaran geometri, dimana siswa perlu mengasah keterampilan dalam menyelesaikan masalah terkait hubungan antara titik, garis, dan bidang pada bangun dimensi dua ataupun dimensi tiga, guru dapat menggunakan media yang tepat sesuai dengan karaketristik materi ajar agar dapat memaksimalkan performa siswa, baik siswa laki-laki maupun perempuan dalam pembelajaran. Selain itu, pembelajaran juga dapat didesain dengan melibatkan kelompok untuk melakukan kegiatan diskusi yang terdiri dari siswa laki-laki dan siswa perempuan 
mengingat kelemahan dan kelebihan masing-masing jenis kelamin dalam memberikan respon terhadap proses pemecahan masalah yang dilakukan.

\section{Daftar Pustaka}

[1] D. L. Sulistiowati, T. Herman, dan A. Jupri, "Student difficulties in solving geometry problem based on Van Hiele thinking level", In Journal of Physics: Conference Series (Vol. 1157, No. 4, p. 042118). IOP Publishing, 2019.

[2] H. Hudojo, Herman, Mengajar Belajar Matematika, Jakarta: Departemen Pendidikan dan Kebudayaan Direktorat Jenderal Pendidikan Tinggi Proyek Pengembangan Lembaga Pendidikan Tenaga Kependidikan, 1988

[3] A. Hidayat, C. Sa'dijah, dan I. M. Sulandra, "Proses Berpikir Siswa Field Dependent dalam Menyelesaikan Masalah Geometri Berdasarkan Tahapan Polya", Jurnal Pendidikan: Teori, Penelitian, dan Pengembangan, vol. 4, no. 7, 923-937, 2019.

[4] S. Ahmad, S. Safee, dan W. M. Afthanorhan, "Learning styles towards mathematics achievements among higher education students", Global Journal of Mathematical Analysis, vol. 2, no. 2, 50-57, 2014.

[5] I. D. Pradika, S. M. Amin, dan S. Khabibah, "Relational Thinking in Problem Solving Mathematics based on Adversity Quotient and Visual Learning Style", International Journal of Trends in Mathematics Education Research, vol. 2, no. 4, 161-164, 2020.

[6] A. Rahman dan A. Ahmar, "Relationship between learning styles and learning achievement in mathematics based on genders", World Transactions on Engineering and Technology Education, vol. 15, no. 1. 2017

[7] A. Bosman dan S. Schulze, "Learning style preferences and Mathematics achievement of secondary school learners", South African Journal of Education, vol. 38, no. 1, 2018.

[8] V. A. Krutetskii, The Psychology of Mathematical Abilities in School Children, Chicago and London: The University of Chicago Press, 1976

[9] Maccoby, E. Eleanor, dan C. N. Jacklin, The Psychology of Sex Differences, Stanford California: Stanford University Press, 1974

[10] G. Polya, How to Solve It A New Aspect of Mathematical Methods, Second Edition, New Jersey. Princeton: Princeton University Press, 1973

[11] G. Polya, Mathematics Discovery On Understanding Learning and Teaching Problem Solving, New York: John Wiley and Sons, 1981

[12] M. Arwanto, I. K. Budayasa, dan M. T. Budiarto, "Students' Intuition in Mathematical Problem-solving at the Stage of Understanding the Polya Problem", In 1st International Conference on Advanced Multidisciplinary Research (ICAMR 2018). Atlantis Press, 2019.

[13] R. J. Purnomo, S. A. Widodo, dan D. S. Setiana, "Profil Berpikir Siswa dalam Memecahkan Masalah Matematis Berdasarkan Model Polya", Range: Jurnal Pendidikan Matematika, vol. 1, no. 2, 101-110, 2020.

[14] L. J. Moeleong, Metodologi Penelitian Kualitatif, Bandung: Rosdakarya, 2007

[15] V. Chislett dan A. Chapman, VAK Visual Auditory Kinesthetic Learning Styles Test Quetionaire. http://www.businessballs.com. Diakses tanggal 9 September 2019

[16] B. M. Miles dan M. A. Hubermen, Analisis Data Kualitatif. Jakarta: UI Press, 1994

[17] R. W. Copeland, Mathematics and The Elementary Theacher $3^{\text {rd }}$ Edition. Philadelphia. London: Toronto. Saunders, W B Company, 1976

[18] M. T. Budiarto, Bentuk Kesalahan dalam Menyelesaikan Permasalahan Geometri, Makalah Disajikan Pada Seminar Nasional Matematika di Universitas Negeri Yogyakarta Juli 2006, Yogyakarta 
Profil Pemecahan Masalah Geometri Siswa MTs ditinjau dari Perbedaan Gaya Belajar dan Jenis Kelamin

[19] Z. Zeybek, "Productive struggle in a geometry class", International Journal of Research in Education and Science, vol. 2, no. 2, 396-415, 2016.

[20] J. Proulx, E. Simmt, dan J. Towers, "RF05: The enactivist theory of cognition and mathematics education research. Issues of the past, current questions and future directions", In Proceedings of the 33rd Conference of the International Group for the Psychology of Mathematics Education, vol. 1, pp. 249-278, 2009. 